\title{
Satellite tailing and fundamental rights: A comparative study
}

\author{
Iovene Federica
}

Does the use of GPS to track people's movements interfere with their right to privacy? The question has been dealt with by the U.S. Supreme Court and by the European Court of Human Rights. Through the analysis of two recent decisions of these Courts, the author reflects on the Italian discipline of such investigative means. As a matter of fact, the Italian Court of Cassation has confronted the same issue, but reached firmly different conclusions which the author does not share.

\section{Introduction}

Tailing - traditionally accomplished through manual annotation and visual documentation of movements and personal contacts - is nowadays carried out using technology, making it more effective and more invasive at the same time. It is, as a matter of fact, possible to continuously monitor people's movements without any fear of losing track of them or of being detected. This so-called "electronic tailing" may be accomplished by exploiting devices already owned by the person under surveillance, which is what happens when their location is obtained by tracking the cell site data generated by their cell phone, or by using specific devices, like the Global Positioning System (GPS) which, usually attached to an individual's vehicle (either on the undercarriage of the car or inside it), gives the exact indication of its location ${ }^{1}$.

The Italian Supreme Court of Cassation finds no significant difference between such technologically characterized tailing and traditional tailing, and considers both as an atypical investigative activity, subject to the admissibility rule of Art. 189 of the Code of Criminal Procedure, which allows the admission of any evidence not specifically regulated by procedural law if it is capable of revealing the facts and does not violate a person's freedom of self-determination. ${ }^{2}$

This conclusion is, the author believes, unacceptable: electronic surveillance is indeed ongoing and pervasive and has a deeper and wider impact on the individual's private life and on their legitimate expectation of privacy. In light of the recent case law of the U.S. Supreme Court and of the European Court of Human Rights, it is

\footnotetext{
${ }^{\star} \mathrm{PhD}$ candidate in criminal procedure at the University of Trento, Italy. This article is originally published in Italian in Cassazione penale, n. 10, 2012, p. 313.

${ }^{1}$ It is not always necessary to physically attach the GPS device to the vehicle of the person to monitor; as a matter of fact, on the one hand, the car could be already equipped with a stolen vehicle detection system that police officers could exploit; on the other hand, new generation cell phones (smart phones) generally include a GPS.

${ }^{2}$ See Cass. Sez. I, 10 gennaio 2012, n. 14529, not published; Cass.Sez. V, 10 marzo 2010, Z. B., in Dir. pen.proc., 2010, p. 1464; Cass. Sez. IV, 29 gennaio 2007, Navarro, in Cass. pen., 2008, p. 1137; Cass. Sez. V, 7 maggio 2004, Massa, in Cass. pen., 2005, p. 3036; Cass. Sez. V, Bresciani, in Cass. pen., 2002, p. 3049.
} 
no longer possible for Italian courts to deny the impact of GPS surveillance on fundamental rights, or to deny the urgent necessity to enact a law specifically describing the conditions under which such a device may be used.

\section{2. "Electronic tailing" in the U.S.}

The starting point of the analysis of the so-called "electronic tailing" in the American system is the Fourth Amendment, which protects people against unreasonable searches and seizures and requires that such activities be authorized by a warrant, issued upon probable cause, particularly describing the place to be searched and the persons or things to be seized. In the absence of legislation, the task of establishing if an activity can be considered a Fourth Amendment search or seizure and if constitutional guarantees must hence apply, has been naturally assumed by the Supreme Court, whose case law has progressively outlined a system aimed at striking a balance between investigative needs and individual rights.

Traditionally, the application of the Fourth Amendment was bound to the protection of property, to the concept of physical trespass resulting from the English Common Law, according to which a search is only carried out when a physical trespass of a constitutionally protected area occurs. ${ }^{3}$ The development of advanced wiretapping technologies, which did not imply any physical trespass, led the Supreme Court, in the late '60s, to reconsider its approach and, in what is still considered the most important precedent in the matter, it introduced a new test to establish when the IV Amendment applies: the reasonable expectation of privacy test. ${ }^{4}$ Such a test, in the formulation resulting from the concurring opinion of Justice Harlan, is two-pronged: in order to determine whether a search has occurred, it is necessary to verify first if the person has exhibited an actual (subjective) expectation of privacy and second, if the expectation of privacy is one that society is prepared to recognize as reasonable. ${ }^{5}$

With particular regard to the "electronic tailing" accomplished through the attachment of a specific device, the conventional approach of the Supreme Court was to distinguish between the installation of the device and the subsequent monitoring. As to the first, a search warrant is generally required because it implies a physical trespass; as to the second, it is usually not considered a search because it involves the obtaining of information knowingly exposed to the public. ${ }^{6}$ It is an extrapolation of the open fields doctrine articulated by Justice Holmes in United

\footnotetext{
${ }^{3}$ This was the approach followed by the Supreme Court in the first wiretapping case. Olmstead v. United States, 277 U. S. 438 (1928).

${ }^{4}$ Katz v. United States, 389 U. S. 347 (1967).

${ }^{5}$ Id. at 361 (Harlan, J., concurring).

${ }^{6}$ See Wayne R. LaFave, Search and seizure. A treatise on the Fourth Amendment, $4^{\circ} \mathrm{ed}$., vol. I, Thomson-West, 2004, at 758 ff.; Dorothy Glancy, Privacy on the open road, 30 Ohio N. U. L. Rev. 295, 297 (2004), at 345 ff.; Gabriella Di Paolo, Tecnologie del controllo e provapenale. L'esperienza statunitense e spunti per la comparazione, Cedam, 2008, p. 173, who observes that "the exposure to the public is often due to necessity rather than to a voluntary choice" and that "reasoning in terms of "intentional choice" to expose oneself to the public or of "free waive of privacy right" is abstract and formalistic".
} 
States $v$. Hester ${ }^{7}$, according to which the special protection of the Fourth Amendment is not extended to public places. ${ }^{8}$ Thanks to this argument the Supreme Court denied that monitoring a person's movements through a beeper, the technological antecedent of GPS, is a Fourth Amendment search; following a reasoning similar to that of the Italian courts, the Supreme Court considers it irrelevant whether or not the perceptive capacities are enhanced by technology: the observation of what is in plain view can by no means be considered a search. ${ }^{9}$ Monitoring a beeper infringes the legitimate expectation of privacy of the target and becomes a search under the Fourth Amendment only when it reveals "a critical fact about the interior" of a home that could not have been obtained by visual surveillance. ${ }^{10}$

\section{The decision in U.S. v. Jones}

The case described illustrated the situation until a recent decision of the Supreme Court, which unanimously held that "the Government's installation of a GPS device on a target's vehicle and its use of that device to monitor the vehicle's movements, constitutes a "search"," 11

This decision is particularly interesting because the majority opinion, overcoming those precedents that made a distinction between the installation of the device and the subsequent monitoring, declares that the two activities imply each other and cannot be considered separately. In Justice Scalia's words "a trespass on "houses" or "effects", or a Katz invasion of privacy, is not alone a search unless it is done to obtain information; and the obtaining of information is not alone a search unless it is achieved by such trespass or invasion of privacy" ${ }^{\prime 2}$.

The majority opinion and Justice Alito's concurring opinion ${ }^{13}$ represent two different approaches to the Fourth Amendment. According to Justice Scalia, writing for the majority, the Katz reasonable expectation of privacy test has been added to, but not substituted for, the common law trespassory test; as a consequence, since in the specific case there had been a physical trespass into an area protected by the Fourth Amendment, there had undoubtedly been a search, requiring a judicial warrant, without any necessity to further investigate whether Jones had a legitimate

\footnotetext{
${ }^{7}$ United States v. Hester, 265 U. S. 57 (1924).

${ }^{8}$ Such a doctrine survives despite the fact that in Katz v. United States, 389 U. S. 347 (1967), the Supreme Court declared that the Fourth Amendment "protects people not places". The basis for this reasoning is the idea that secrecy, or at least the effort made to keep a certain activity reserved, is a prerequisite for privacy.

${ }^{9}$ United States v. Knotts, 460 U. S. 276 (1983).

${ }^{10}$ United States v. Karo, 468 U.S. 705, 715 (1984). A different trend in the State Courts' case law must be acknowledged. For instance, the Supreme Court of Oregon held the existence of a constitutional right to freedom from technologically advanced scrutiny, which would be infringed by the use of tracking devices, such as the beeper, that enable the police to continuously monitor a person's movements. See State v. Campell, 759, P.2d 1040 (Or. 1988). In a case involving the use of GPS, the Supreme Court of Washington, though upholding its legitimacy because its installation and use were authorized by judicial warrants, underlined the particular invasiveness of such a device, capable of revealing a great deal of information about an individual's life. See State v. Jackson, 76 P.3 217 (Wash. 2003). See also Doroty Glancy, Privacy on the open road, supra note 6, at $329 \mathrm{ff}$.

${ }^{11}$ United States v. Jones, 132 S. Ct. 945 (2012).

${ }^{12}$ United States v. Jones, 132 S. Ct. 945 (2012), majority opinion footnote 5.

${ }^{13}$ Joined by Justices Ginsburg, Breyer and Kagan.
} 
expectation of privacy. ${ }^{14}$ On the contrary, Justice Alito, in his concurring opinion, affirms the necessity to always apply the Katz test in order to ascertain if there has been a violation of the person's reasonable expectation of privacy; for the purposes of this inquiry, he suggests considering the duration of the surveillance and he claims that a judicial warrant is deemed necessary only in case of long-term GPS monitoring. ${ }^{15}$

The innovatory significance of the Jones decision, however, fades when considering that its holding applies only to those cases in which it is necessary to physically install the GPS device. The hypothetical case in which, on the contrary, the Government exploits a device already present in the car or in the cell phone of the monitored person, thus realizing only an electronic invasion of their property or privacy, remains subject to the previous case law. The majority opinion hints at the possibility that this could be an unconstitutional invasion of the reasonable expectation of privacy of the target, but does not deem it necessary to further develop this point, since it is not required for the solution of the case under examination.

Hence the situation remains uncertain.

The concurrence of Justice Alito, who asserts that the use of long-term GPS monitoring, despite a physical trespass, impinges on the reasonable expectation of privacy, might be followed and further developed by the courts, but it is clearly not a binding precedent.

Moreover, while it is true that in Kyllo v. United States ${ }^{16}$ the Supreme Court also included in the area of protection of the Fourth Amendment the "technological equivalent of the physical trespass", it must also be underlined that in that case an intrusion into the home, to which the jurisprudence grants the highest protection, had taken place. It is then legitimate to doubt that such precedent is applicable to cases in which there is only an "electronic trespass"; as a matter of fact, the Supreme Court, like the Italian Supreme Court of Cassation, distinguishes between domicile, constitutionally protected areas and public places, and in the Jones decision it simply qualifies the vehicle as an "effect", thus sanctioning a violation of the property right, without facing the crucial question of whether there might be a reasonable expectation of privacy also in public places.

The fear is that the courts will continue to apply the plain view doctrine, thus denying the necessity of a judicial warrant authorizing the use of electronic tracking devices, when no physical trespass occurs. ${ }^{17}$

\footnotetext{
${ }^{14}$ Jones' car is considered an "effect", hence one of the objects expressively protected from the Fourth Amendment. It must be underlined, however, that the car is not considered a constitutionally protected area, thus an area in which the person enjoys a legitimate expectation of privacy, but only the object of a property right.

${ }^{15}$ Justice Alito points out that the majority's approach fails to consider the cases in which surveillance is carried out by making electronic, as opposed to physical, contact with the item to be tracked, which is what happens when the car is already equipped with GPS and the police simply exploit it.

${ }^{16}$ Kyllo v.United States, 533 U. S. 27 (2001). The Supreme Court held that the use of a device not in general public use, a thermal imager, was a search under the Fourth Amendment and therefore required a judicial warrant because it allowed the observation of activity or details that would be unobservable without physical intrusion into the domicile.

${ }^{17}$ Courts will most likely continue to apply Knotts and Karo and to require a warrant only when the monitoring involves the domicile.
} 
A glimmer of hope might stem from the opinion concurring in the judgment of Justice Sotomayor, who affirms that technological evolution imposes an adaptation to contemporary society: secrecy must not be considered a prerequisite for privacy, and the individual should be granted a reasonable expectation of privacy even with regard to the information voluntarily disclosed to the public.

The wish is that in the future, if required to decide upon a case where there has been no physical trespass, the Supreme Court will further develop such arguments and settle the key question of the existence of a legitimate expectation of privacy also in public.

\section{The decision Uzun v. Germany of the European Court of Human Rights}

The European Court of Human Rights has dealt with the same question. ${ }^{18}$ Following an entirely different approach from the American Supreme Court, the Strasbourg Judges declared that the applicant observation via GPS interfered with his private life as protected by Article $8 \S 1 \mathrm{ECHR}$. In particular, they recognized that there is a private sphere also deserving protection in public and relational life; as a matter of fact, Art. $8 \mathrm{ECHR}$ protects not only the right to identity and personal development, but also the right to establish and develop relationships with other human beings. ${ }^{19}$ As a consequence, the so-called "electronic tailing", as well as all the other measures that interfere with the exercise of such a right, must be regulated by the law and constitute a measure that is "necessary in a democratic society in the interests of national security, public safety or the economic-well being of the country, for the prevention of disorder or crime, for the protection of health or morals, or for the protection of the rights and freedoms of others" 20 .

The Court, however, recognizes that the GPS monitoring of movements in public spaces interferes less with the private life of the person concerned than other measures of visual or acoustical surveillance, which usually disclose more information on a person's conduct, opinions or feelings, and therefore admits that the requirements national law ${ }^{21}$ should have in order to comply with Art. 8 ECHR are wider than those of telecommunications wiretapping. Such a law must provide adequate protection against arbitrary interference with private life and be clear with regard to the conditions of its applicability; it must indicate "the nature, the scope and duration of the possible measures, the grounds required for ordering them, the

\footnotetext{
${ }^{18}$ European Court of Human Rights, Uzun v. Germany, 2 September 2010, application no. 35623/05.

19 The European Court of Human Rightshas repeatedly held that under Article 8 ECHR the recording of data and the systematic or permanent nature of the record constitutes itself an interference with the individual's private life, even if the monitored activities are carried out in public and do not have an intimate nature. See, European Court of Human Rights, Peck v. United Kingdom, 23 January 2003, application no. 44647/98, \$§ 57-59; P.G. and J. H. v. United Kingdom, 25 September 2001, application no. 44787/98, \$§ 56-57, Perry v. United Kingdom, 17 July 2003, application no. 63737/00, §§ 36-38; Rotaru v. Romania, 4 May 2000, application no. 28341/95, §§ 43-44.

${ }^{20}$ Art. 8 \& 2 ECHR.

21 The term "law" includes not only written law but also judge-made law.
} 
authorities competent to permit, carry out and supervise them, and the kind of remedy provided by the national law". 22

Bearing in mind all these circumstances, the Court considers that in the specific case the interference with the applicant's right to respect for his private life was "in accordance with the law" within the meaning of Article $8 \S 2 \mathrm{ECHR}^{23}$

The decision under examination is particularly significant first of all because it contrasts the idea that secrecy is a prerequisite for the protection of privacy ${ }^{24}$; secondly, because it acknowledges the existence of various levels of limitation of private life, depending on the different kinds of information obtained and the place in which it is collected, with the consequence that the necessary discipline of the diverse surveillance technologies can, or better, must be differentiated with regard to its applicability conditions and to the identification of the authority competent to adopt the measure. ${ }^{25}$

\section{GPS monitoring in the Italian system}

The Italian Supreme Court of Cassation considers the activity aimed at locating and monitoring a person's movements in public spaces as a "technologically characterized tailing", and, as such, falling within the ordinary investigation activity police can conduct without any authorizing warrant, according to Articles 55, 347 and 370 of the Italian Code of Criminal Procedure (hereinafter c.p.p.). ${ }^{26}$ The Court denies that such means of investigation might infringe the constitutional right to the freedom and secrecy of communication and that therefore it might require the application of the wiretapping discipline. ${ }^{27}$ The "electronic tailing" is considered an atypical investigation activity, the results of which are admissible as evidence under the conditions established by Article 189 c.p.p.; neither its capability of determining the facts nor the lack of detriment for the person's freedom of self-determination

\footnotetext{
${ }^{22}$ Uzun v. Germany, supra note 18 , at $\S 63$.

${ }^{23}$ The measure had been adopted under Article $100 \S 1$ no. 1(b) of the German Code of Criminal Procedure, which admits the possibility to use special technical means - other than the typical ones - intended for the purpose of surveillance when the investigation concerns a criminal offense of considerable gravity and if other means had less prospect of success or were more difficult. This was the prevision considered by the Strasbourg Court and held compatible with Art. 8 ECHR. On November 1, 2000, Article $163 \mathrm{f}$ of the Code of Criminal Procedure on longterm (more than 24 hours) systematic surveillance of suspects, entered into force. According to this article, such measure could only be ordered in respect of persons suspected of an offense of considerable gravity and if other means of investigating the facts of the case were considerably more difficult. The measure has to be adopted by the public prosecutor if it lasts less than a month; any further extension can only be ordered by a judge.

${ }^{24}$ It is interesting to notice the similarity with the concurring opinion of Justice Sotomayor in Jones v. Unites States, supra note 11 .

${ }^{25}$ Particularly interesting to this extent is the parallel the Court makes with the discipline of telecommunication wiretapping. See $\S \S 65-66$ of the decision.

${ }^{26}$ See supra note 2 .

${ }^{27}$ Article 15 of the Italian Constitution states that "the freedom and secrecy of correspondence and of every other form of communication is inviolable. Restrictions thereto may be imposed only by a warrant that gives the reasons issued by judicial authority with the guarantees established by law". Accordingly, Articles 266-271 of the Code of Criminal Procedure describe the wiretapping proceeding identifying the cases in which such an investigative measure can be used and specifying that it can be ordered by the judge upon request of the public prosecutor. It must be noted that in the Italian system, the judiciary encompasses both judges and public prosecutors.
} 
are brought into question, since the monitored person is unaware of the surveillance.

Such a conclusion does not convince. In the first instance, as sharply noticed by American scholars, just the simple realization that a pervasive and ongoing surveillance of one's movements is possible, persuades one to change one's way of life, affects one's freedom of choice and self-determination (the so-called Panopticon Effect $) ;{ }^{28}$ in the second instance, even if the assumption that "electronic tailing" does not interfere with the freedom and secrecy of communication is sharable, Article 15 of the Italian Constitution is not the only fundamental right which might be affected by such an activity.

Various are the hypotheses proposed by the Italian scholars. First of all, it has been claimed that the vehicle, being a delimited space, preordained at the development of private life, should be considered an area worth constitutional protection. The jurisprudence refuses to consider it similar to the domicile and therefore denies the involvement of Art. 14 of the Constitution ${ }^{29}$, but at the same time it has elaborated the category of "private domains other than the home", protected by Article 2 of the Constitution. ${ }^{30}$ The inclusion of the vehicle in this category would entail the necessity of a pre-authorization by the public prosecutor for the "electronic tailing". 31

Moreover, it has been underlined that satellite tailing, discouraging certain movements, is able to impinge on the freedom of circulation, protected by Art. 16 of the Constitution, encompassing the "right to be free from technological localization"; 32 it therefore requires a specific regulation, in accordance with Art. 16 of the Constitution, which states that any limitation of the freedom of circulation may be established only by the law.

Finally, it has been held that such investigative measure limits personal liberty, meaning also moral freedom, granted by Article 13 of the Constitution, and that therefore any restrictions of it are admissible only by means of a warrant that states

\footnotetext{
28 The reference is to Jeremy Bentham's Panopticon, a model prison built in such a manner that every prisoner would be always visible to guards, wherever he or she was. Bentham proved that the mere idea of being constantly watched caused the prisoners to behave as if they were chained in their cells. See Dorothy Glancy, Privacy on the open road, supra note 6, at $320 \mathrm{ff}$.; Christopher Slobogin, Public privacy: Camera surveillance of public places and the right to anonymity, 75 Miss. L. J. 213 (2002), at $24 \mathrm{ff}$., who theorizes the existence of a right to anonymity, understood as a constitutional right "to be free from intensive government scrutiny even in public, absent suspicious conduct"; Jeffrey Remain, Driving to the Panopticon: A philosophical exploration of the risks to privacy posed by the highway technology to the future, 11 Santa Clara Computer \& High Tech. L.J. 27 (1995). In Italy for similar concerns see Gabriella Di Paolo, Tecnologie, supra note 6 , p. 268, who affirms that the systematic control of people's movements impinges on fundamental public freedoms: the right to assemble, preordained also to the exercise of the freedom of expression, of political rights, of freedom of religion and of personal liberty.

${ }^{29}$ Article 14 of the Constitution states that "the domicile is inviolable. Inspections or searches or seizures may not be carried out except in the cases and in the manners established by the law in accordance with the guarantees prescribed for the safeguard of personal freedom. Controls and inspections for reasons of public health and safety or for economic and fiscal purposes are regulated by special laws".

${ }^{30}$ Such a category has been originally developed with regard to video surveillance from Cass. Sez. Un., 28 marzo 2006, Prisco, in Cass. pen., 2006, p. 3940. Article 2 of the Constitution recognizes and guarantees the inviolable rights of human beings.

${ }^{31}$ See Gabriella Di Paolo, Tecnologie, supra note 6, p. 256.

${ }^{32}$ See Alberto Camon, L'acquisizione dei dati sul traffico delle comunicazioni, in Riv.it. dir. e proc. pen., 2005, p. 633.
} 
the reasons issued by a judicial authority and only in the cases and manners provided for by the law; the lack of a specific regulation would render the "electronic tailing" unconstitutional, thus forcing the judge to apply the exclusionary rule of Art. $191 \mathrm{c}$. $p \cdot .^{33}$

\section{The impact of the decision Uzun v. Germany in the Italian system}

The European Court of Human Rights, although in a case regarding Germany, affirmed that GPS surveillance interferes with the right to private life, protected by Article 8 of the Convention.

According to the Italian Constitutional Court, the legal basis of Art. 117, par. 1 of the Constitution, insofar as it imposes that legislative power is exercised by the State and the Regions in compliance with the Constitution and with the constraints deriving from European Union law and other international obligations, guarantees $^{34}$, within the Italian system of the sources of law, an "infra-constitutional" rank to the ECHR, which therefore becomes a new "intermediate source" of the judgment of constitutionality. ${ }^{35}$

Hence, two consequences may be drawn: first of all, Italian courts are no more allowed to deny that satellite tailing interferes with fundamental (or better constitutional) rights; secondly, such activity must be disciplined by the law and deemed necessary to pursue one of the legitimate aims mentioned by Art. 8 ECHR.

In general terms, in order to be considered "in accordance with the law" a measure should have some basis in domestic law - both written law and judge-made law - and must be accessible to the person concerned, who must, moreover, be able to foresee its consequences for him. ${ }^{36}$ With regard to the use of GPS to monitor a person's movements, the European Court of Human Rights, as already mentioned, clarified that Art. 8 of the Convention is respected if the "law" indicates "the nature, the scope and duration of the possible measures, the grounds required for ordering them, the authorities competent to permit, carry out and supervise them, and the kind of remedy provided by the national law". 37

\footnotetext{
${ }^{33}$ Art. 191 c.p.p. states that evidence acquired in violation of the law may not be used at trial. The Constitutional Court affirmed that evidence obtained in violation of the Constitution falls within this prohibition and that the trial judge is entitled to declare that such violation occurred, without any need to address the issue to the Constitutional Court. See, Leonardo Filippi, Il GPS è una prova incostituzionale? Domanda provocatoria, ma non troppo, dopo la sentenza Jones della Corte Suprema U. S. A., in Arch. pen., 2012, n. 1.

${ }^{34}$ The provision is interpreted so that the duty to respect and perform international obligations affects univocally and globally the content of domestic legislation, the validity of which cannot depend on which point of view is under consideration, or on the reciprocal limitation of competences between State and Region, rather than on the extent of State legislative power as a whole.

35 C. cost., 24 ottobre 2007, n. 348, in Giur. cost., 2007, p. 3475; C. cost., 24 ottobre 2007, n. 349, in Giur. cost., 2007, p. 3535. See also C.cost., 26 novembre 2009, n. 311, in Giur. cost., 2009, p. 4657; C. cost., 4 dicembre 2009, n. 317, in Giur. cost., 2009, p. 4747. The decisions may be found also on www.corte costituzionale.it.

${ }^{36}$ With particular regard to the requirement of legal "foreseeability" in the context of covert measures of surveillance, the law must be sufficiently clear in its terms to give citizens an adequate indication of the conditions and circumstances in which the authority are empowered to resort to any such measure. See Uzun v. Germany, supra note 18 , at $§ 61$.

${ }^{37}$ Uzun v. Germany, supra note 18 , at $\$ 63$.
} 
The discipline deriving from the interpretation of Articles 55, 347, 348, 370 and 189 of the Italian Code of Criminal Procedure, which define an atypical investigation activity, led by the police without any judicial authorization, does not comply with these standards; as a consequence, the Italian "regulation" of GPS surveillance contrasts with Articles 8 ECHR and 117, par. 1 of the Italian Constitution.

This conclusion, however, does not allow courts to declare such a measure unconstitutional and to directly apply the exclusionary rule of Art. 191 c.p.p. As a matter of fact, according to the recent decisions of the Constitutional Court, conventional law, differently from EU law, does not have direct effect on the domestic order, so that in case of contrast between the internal provision and the conventional one, national judges cannot directly apply the Convention in trials they are dealing with, and at the same time not apply the internal provisions in potential conflict with it. National Judges should, on the contrary, first try to interpret the national provision so that it is compatible with the Convention, and, only if this is not possible, refer the question to the Constitutional Court, claiming a potential violation of Art. 117, par. 1 Cost. ${ }^{38}$

Unlike what Italian courts claim, the application of the "minimum guarantee standard" consisting of a well-grounded pre-authorization by judicial authorities, does not constitute an interpretation compatible with the Convention. Such reasoning has been applied to the acquisition of stored communications data ${ }^{39}$, covert video surveillance in private domains different from the home ${ }^{40}$, and finally registration of communications by one of the interlocutors with the help of instruments provided by the police ${ }^{41}$, and moves from the assumption that in those cases the level of intrusion in the private life of the person would be lower than that caused by the typical measure, i. e. wiretapping, and therefore a lower level of guarantees, consisting in a well-founded warrant issued by the public prosecutor, would be acceptable.

Such hermeneutic effort, if adopted with regard to satellite tailing, would not in any event be sufficient to avoid the control of the Constitutional Court. As a matter of fact, Art. 8 ECHR expects national law - not only written law, but also case law, provided that it consists of a steady and uncontested orientation, which gives life to a knowable and foreseeable discipline - to mention not only the competent authority, but also the nature, scope, and duration of the measure, the grounds required for ordering it, and the kind of remedy given to the target.

\footnotetext{
${ }^{38}$ C. cost., 11 marzo 2011, n. 80, in Giur. cost., 2011, p. 1224 and on www.cortecostituzionale.it. No different conclusions may be drawn from the entrance into force of the Treaty of Lisbon which, allowing for the accession of the European Union to the ECHR, would transform the latter into a directly applicable source of law, so that it would enjoy the same regime as that of the Union's law, first of all because such accession has not occurred yet, and secondly because, in any case, the direct application of EU-general principles, including those of the ECHR, in the domestic legal order would only be possible in the fields in which the Union is competent.

${ }^{39}$ Cass., Sez. Un., 23 febbraio 2000, D'Amuri, in Giur. it., 2001, p. 1707.

40 Cass. Sez. Un., 28 marzo 2006, Prisco, supra note 30.

${ }^{41}$ Cass., Sez. IV, 7 aprile 2010, Angelini, in C.E. D.Cass., n. 247384. In this decision, the Supreme Court of Cassation affirms that "the pre-authorization by the judicial authority, either the judge or the public prosecutor, is itself able to grant the respect of Art. $8 \mathrm{ECHR}$, as interpreted by the European Court of Human Rights, since it offers adequate protection against arbitrary interference with private life". See the comment of Piero Gaeta, Per utilizzare registrazioni fra presenti fatte dalla Pg è sufficiente un decreto del pubblico ministero, in Guida dir., 2010, p. 75.
} 
While waiting for a no longer postponable intervention of the Legislature ${ }^{42}$, the only temporary solution is to refer to the Constitutional Court, claiming a contrast with Articles 8 ECHR and 117, par. 1 of the Constitution of the discipline deriving from the interpretation of Articles 55, 347, 370 and 189 c.p.p., in so far as it considers electronic tailing an atypical investigation activity police can conduct on their own initiative.

\footnotetext{
${ }^{42}$ Not only Germany, but also several American States (California, Hawaii, Oregon, Pennsylvania, Tennessee, Texas, Utah) and Canada (Section 492.1 of the Criminal Code, introduced in 1993) have enacted laws or statutes explicitly regulating electronic tailing; such a regulation usually provides for the prerequisites, duration and grounds required for ordering the measure and the authority competent to order it. See Gabriella Di Paolo, Judicial investigations and gathering of evidence in a digital online context, in International Review of Penal Law, 2009, p. $226 \mathrm{ff}$. , and Dorothy Glancy, Privacy, supra note 6, at $351 \mathrm{ff}$.
} 
